\title{
Inheritance of seed characteristics in soybean progenies from grain type $x$ food type crosses
}

\author{
L.C.A. Araujo ${ }^{1}$, A.C.P. Juhász ${ }^{2}$, C.V.G. Azevedo ${ }^{1}$, I.M. Bárbaro-Torneli ${ }^{3}$, \\ V.F. Vianna ${ }^{1}$, A.O. Di Mauro ${ }^{1}$ and S.H. Unêda-Trevisoli ${ }^{1}$ \\ ${ }^{1}$ Universidade Estadual Paulista Júlio de Mesquita Filho, Faculdade de \\ Ciências Agrárias e Veterinárias de Jaboticabal, Departamento de Produção \\ Vegetal, Jaboticabal, SP, Brasil \\ ${ }^{2}$ Empresa de Pesquisa Agropecuária de Minas Gerais, Departamento de \\ Genética e Melhoramento, Uberaba, MG, Brasil \\ ${ }^{3}$ Agência Paulista de Tecnologia dos Agronegócios, Pólo Regional de \\ Desenvolvimento Tecnológico dos Agronegócios da Alta Mogiana, \\ Departamento de Descentralização do Desenvolvimento, Colina, SP, Brasil
}

Corresponding author: V.F. Vianna

E-mail: vfvianna@gmail.com

Genet. Mol. Res. 18 (4): gmr18372

Received May 29, 2019

Accepted August 07, 2019

Published October 30, 2019

DOI http://dx.doi.org/10.4238/gmr18372

\begin{abstract}
Focusing on the genetic traits, seed coat and hilum pigmentation, in soybeans destined for human consumption is necessary due to the relevance of these traits for product acceptability by the consumer market. We investigated the traits seed coat, hilum color and bleeding hilum, in $\mathrm{F}_{2: 3}$ populations originating from crosses between the soybean grain type ('BRSMG $810 \mathrm{C}^{\prime}$ with yellow seed coat, black hilum, and gray pubescence; bleeding hilum and white flower) with food types ('BRSMG 790A' with yellow seed coat and hilum, brown pubescence, no bleeding hilum and purple flower; 'BRSMG 800A' with brown seed coat and hilum, brown pubescence, no bleeding hilum and purple flower).We evaluated 317 plants from cross A ('BRSMG 810C' x 'BRSMG 790A') and 357 plants from cross B ('BRSMG 810C' x 'BRSMG 800A'). The resulting progenies adjusted to the expected ratio, considering four genes (R/I/W/T) controlling the expression of seed coat and hilum pigmentation for both crosses. In cross B, genotypes ii prevented the expression of the $\mathrm{W}$ and $\mathrm{T}$ alleles in the seed coat pigmentation. The expression of the
\end{abstract}


bleeding hilum phenotype varied and presented monogenic inheritance, with complete dominance for no bleeding hilum. The genes responsible for bleeding hilum are linked with the $T_{-}$genotype (brown pubescence). Thus, in these crosses,hybridization was an efficient means to obtain genetic variability. This will aid in the production of for food grade soybean cultivars.

Key words: Hilum aspect; Genetic control; Expressiveness; Glycine max; Seed coat

\section{INTRODUCTION}

The soybean, [Glycine max (L.) Merrill] (Fabaceae) is an annual crop whose grains are used for cattle feed and for human consumption (food-grade soybeans); consumption of the latter has been increasing lately due to soybeans' nutraceutical properties. Therefore, the development of superior conventional genotypes with specific traits related to grain appearance is desired. Among them, seed coat and hilum pigmentation are genetic traits that favor acceptance by the consumer market, along with technological characteristics such as adequate cooking time, adaptation of soybean taste to the palate, and improvement of the seed chemical composition (Juhász et al., 2014).

According to their different uses, soybean cultivars are classified as grain-type, which are conventional soybeans for oil and animal feed, and food-type, which are those for human consumption in fermented foods (misso, tempeh and natto) and non-fermented foods (tofu, soy flour and soy milk). Therefore, soybean cultivars for human consumption should present special chemical, physical and sensory characteristics. Evaluation ofe chemical (genetic elimination of lipoxygenase enzymes to improve the flavor of soy food products, for example) and physical characteristics of grains of soybean cultivars for food processing (tofu, soy milk, edamame, soybean sprouts production, natto) are commonly used in a breeding program for these specific objectives as such as presented by Silva et al. (2009).

Visual appearance is important for direct consumption of soybeans. The soybean seed changed because of domestication during the transition from Glycine spp. to the current G. $\max$. As a consequence of the selection process, modern commercial cultivars of high-quality G. max have yellow-coated seeds with a range of hilum colors (brown, black, imperfect black, gray and yellow) (Senda et al., 2012; Carpentieri-Pipolo et al., 2015). Morphological characteristics such as hilum and seed coat color do not affect soybean use by the industry; however, seed coat and hilum are required to have the same color when supplying the demand for direct consumption as human food. Likewise, bleeding hilum was not a morphological trait considered unwanted when selecting genotypes for industry, although it is relevant for human consumption.

For human consumption, the grains must be uniform, the tegument and the hilum must be the same color, there must not be spillage of the hilum, the tegument cannot present imperfections such as splits, stains caused by diseases and pests, mechanical damage; these are characteristics used as parameters of acceptance by consumers (Juhász et al., 2014). Identification of seeding pigmentation patterns is a valuable approach for differentiating soybean cultivars (Payne and Morris, 1976). In Brasil (1997), the characterization of soybean cultivars is based on the Plant Variety Protection Law regulated by the Lei $\mathrm{n}^{\circ}$ 
9.456, de 25 de abril de 1997, which indicates that the seed coat and hilum pigmentation are obligatory morphological descriptors that should obey the distinguishing characteristics and homogeneity and stability criteria for protecting new genetic variations in the National Service of Protection of Cultivars of the Ministry of Agriculture, Livestock and Supply (SNPC/MAPA).

Although classified as a qualitative characteristic and, therefore, involving simple inheritance, the genetic control for seed coat and hilum pigmentation in soybean presents allelic interactions with the genes involved in the control of the pubescence and flower color (Vernetti and Vernetti Júnior, 2009; Nogueira et al., 2015). The phenotypic variations of hilum color may be associated with environmental effects due to changing temperature and humidity during seed developments. Molecular markers can help in the genetic determination of soybean seeds regarding hilum color since phenotypic traits may undergo environmental influence (Rabel et al., 2010).

The seed coat and hilum color in soybean seeds are expressed by the interaction and expression of six main genes. The first, $\mathrm{G}$ gene, in which the $\mathrm{G}$ allele is dominant, confers the green phenotype; the $\mathrm{g}$ allele imparts yellow pigment (Terao, 1918). The $\mathrm{R}$ gene in which the black pigment ( $R_{-}$) is dominant over the brown pigment (rr) (Nagai, 1921; Woodworth, 1921), besides possible seeds with black streaks on brown pigments $\left(\mathrm{r}^{\mathrm{m}}\right)$ (Weiss, 1970). Recent studies suggest that the loss of R2R3 MYB gene function is responsible for the expression of brown color in soybean seeds (Gillman et al., 2011). The inheritance of the black and brown pigments is said to be independent of the green and yellow pigments (Yang et al., 2010).

Gene I, with alleles that may, in the order of dominance of the allelic series presented $\left[\left(\mathrm{I}>\mathrm{i}^{\mathrm{k}}>\mathrm{i}^{\mathrm{i}}>\mathrm{i}\right)\right.$, inhibit the total pigmentation of anthocyanins and proanthocyanins in the seed (I); allow the hilum pigmentation to bleed/extend beyond the hilum boundaries $\left(\mathrm{i}^{\mathrm{k}}\right)$; pigmentation restricted to the hilum $\left(\mathrm{i}^{\mathrm{i}}\right)$, and non-inhibition of seed pigmentation (i)] (Nagai, 1921; Woodworth, 1921; Owen, 1927; Morse and Cartter, 1937; Williams, 1952; Mahmud and Probst, 1953; Bhatt and Torrie, 1968).

Gene T: controls the pubescence color (T: dark brown, $\mathrm{t}^{\mathrm{r}}$ : light brown, and $\mathrm{t}$ : gray) and modifies the effects of the allelic series R (Woodworth, 1921). Thus, R_T_genotypes present black seeds while the rrT_ have brown seeds. Genotypes rrtt may have light brown phenotype (Nagai, 1921; Woodworth, 1921).

Gene W that controls the flower color [purple flower (W_) and white flower (ww)] also modifies the effects of the allelic series $\mathrm{R}$. In the presence of ttww and $t \mathrm{tW}$, the $\mathrm{R}_{-}$ genotypes are light brown and imperfect black, respectively. Alleles conditioning the flower color were mapped in the linkage group B2 (Yang et al., 2010), in addition to the gene O, which modifies the seed coat from brown to reddish-brown in the double-recessive (rrT_oo), and the presence of seeds with reddish-brown seed coat and black streaks (Nagai, 1921; Woodworth, 1921; Mahmud and Probst, 1953).

The gene interaction and action on morphological traits of soybean seeds are described as relatively simple genetic control. However, it is necessary to understand better the breeding programs for human feeding in specific populations, where the genetic variability for seed coat and hilum pigmentation is increased by hybridization between grain type and food type crosses, to add agronomic traits of interest to the generated populations. The objective of this work was to examine the inheritance of coat seed and hilum 
pigmentation, as well as bleeding hilum in two crosses from soybean genotypes of food type $\mathrm{x}$ grain types.

\section{MATERIAL AND METHODS}

The hybridizations of the parents that originated the $F_{1}$ and $F_{2}$ generations were conducted in a greenhouse, while the $\mathrm{F}_{2: 3}$ genotypes were obtained in the field. Contrasting genotypes were used for bleeding hilum and hilum color (Crossing A) and contrasting genotypes for bleeding hilum, hilum color, and seed coat color (Crossing B).

The cultivars 'BRSMG 790A', 'BRSMG 810C' and 'BRSMG 800A' were used to develop cross breedings $\mathrm{A}$ and $\mathrm{B}$ by the Embrapa/ Epamig/ Triângulo Foundation partnership. The suffix "A" of cultivars 'BRSMG 790A' and 'BRSMG 800A' designate cultivars developed with special characteristics for human consumption.

'BRSMG 790A' is a conventional soybean cultivar with organoleptic, nutritional and industrial characteristics favorable to human consumption and the food industry. It has large grains, yellow hilum and seed coat, no bleeding hilum with high rates of carbohydrates that confer a mild flavor, although not free of lipoxygenases enzymes (Juhász et al., 2014).

The conventional cultivar 'BRSMG 800A' is the first brazilian soybean cultivar with brown hilum and seed coat, no bleeding hilum, whose physical characteristics, after cooking, closely resemble those of carioca-type beans, improving acceptability of soybeans for human consumption (Juhász et al., 2014). The main phenotype of cultivar 'BRSMG $810 \mathrm{C}^{\prime}$ is the resistance of races 1 and 3 to the soybean cyst nematode (SCN). Morphologically, this cultivar has yellow seed coat and black hilum with bleeding (the hilum color extrapolates to the seed coat shaped as an inverted saddle), exhibiting resistance to other pathogens, including bacterial pustule and stem canker, and high protein content as well (41.66\%) (Arantes et al., 2010).

The two resulting crosses were named as crossing A - 'BRSMG 810C' x 'BRSMG 790A' and crossing B - 'BRSMG 810C' x 'BRSMG 800A'. The $\mathrm{F}_{1}$ generation was obtained following the procedures described by Borém and Miranda (2005) with stepped planting in 3-day intervals to synchronize the flowering between the late cycle parent ('BRSMG 810C') used as a female genitor, and the semi-late cycle parents ('BRSMG 790A' and 'BRSMG $800 \mathrm{~A}^{\prime}$ ) used as male genitor.

The hybrid seeds were multiplied by cropping them in 20 liter pots filled with a substrate made by mixing latosol and sifted corral manure. Three $F_{1}$ plants were grown per pot to obtain $\mathrm{F}_{2}$ seeds and crossbreeding was confirmed by using the hypocotyl color as a morphological marker. After the emergence of the $F_{1}$ seeds, the crossbreeding was confirmed by the contrast between the parents with white flower and green hypocotyl ('BRSMG 810C') and purple flower and purple hypocotyl ('BRSMG 790A' and 'BRSMG $800 \mathrm{~A}^{\prime}$ ) in the crossing schematics, with the genotype with purple hypocotyl dominant over the green hypocotyl phenotype expression.

The seeds of 317 and $357 \mathrm{~F}_{2: 3}$ plants from crosses $\mathrm{A}$ and $\mathrm{B}$, respectively, were cropped using a seed plotter at a sowing density of 20 plants. $\mathrm{m}^{-1}$ arranged in 8 rows $5 \mathrm{~m}$ long, $0.50 \mathrm{~m}$ apart, including the parents to allow predictions of environmental variations and to evaluate the expression of the studied traits. The crop was managed following the procedures adopted in the region. 
The plants were harvested at the phenological stage R8 (Fehr and Caviness, 1977). After harvesting, the $\mathrm{F}_{2: 3}$ seeds were cleaned, packed in paper bags of approximately 100 grams, and later stored in a cold room, for later phenotyping. The $\mathrm{F}_{2: 3}$ plants underwent visual evaluation using the SNPC/MAPA criteria for the following morphological descriptors of phenotype, seed coat color, pubescence and hilum color, as well as the presence of bleeding hilum.

The seed coat was classified according to phenotype as yellow, light brown, medium brown, dark brown and black while the phenotypes light brown and brown were grouped in the brown phenotype class for the segregation analyses. The hilum color was classified as gray, yellow, light brown, brown, black and imperfect black with the light brown and brown grouped in the brown phenotype class whereas black and imperfect black were grouped into the black phenotypic class. Also, the bleeding hilum was classified as either present or absent whereas pubescence color phenotype was classified as brown or gray for all generations. The flower color of $F_{1}$ genotypes and parents was classified as white or purple, for confirmation of hybridization.

After grouping into phenotypic classes of genotypes $F_{1}, F_{2}$ and parents, the frequencies observed for each trait were compared by expected frequencies by the chisquare test $\left(X^{2}\right)$ to verify the fit for the proposed gene models. The $X^{2}$ was estimated using the Genes software (Cruz, 2013). To test the hypothesis, was considered the genes R, I, T and $\mathrm{W}$ for expressing the traits color of hilum and seed coat, $\mathrm{W}$ for expressing flower color, and $\mathrm{T}$ for pubescence color while the monogenic hypothesis was tested for bleeding hilum.To accept the null hypothesis implies that expected segregations are equal or very close to those observed, at $5 \%$ probability.

\section{RESULTS AND DISCUSSION}

All the seeds from $F_{1}$ plants at each crossing showed similar phenotyping for the different morphological descriptors under study (Table 1), which indicates that the parents present the alleles of the genes of these characters in homozygous $\left(X^{2}=0.000 ; \mathrm{P}=100 \%\right)$.

Table 1. Flower color, seed coat color, hilum color, bleeding hilum and pubescence color of the parents 'BRSMG 790A' (Parent $1-\mathrm{P}_{1}$ ), 'BRSMG 800A' (Parent $2-\mathrm{P}_{2}$ ) and 'BRSMG 810C' (Parent $3-\mathrm{P}_{3}$ ), and $\mathrm{F}_{1}$ generations resulting from the crosses A ('BRSMG 810C'x 'BRSMG $790 \mathrm{~A}$ ') and B ('BRSMG $810 \mathrm{C}$ ' $\mathrm{x}$ 'BRSMG 800 A') of soybean.

\begin{tabular}{|c|c|c|c|c|c|c|c|}
\hline \multirow[b]{2}{*}{ Croes } & \multirow[b]{2}{*}{ Generation } & \multirow[b]{2}{*}{ Genotypes } & \multicolumn{4}{|c|}{ Phenotype } & \multirow[b]{2}{*}{$\begin{array}{l}\text { Pubescence } \\
\text { color }\end{array}$} \\
\hline & & & Flower color & $\begin{array}{l}\text { Seed coat } \\
\text { color }\end{array}$ & Hilum color & $\begin{array}{l}\text { Bleeding } \\
\text { hilum }\end{array}$ & \\
\hline & $\mathrm{P}_{1(\text { ) }}$ & rrIITTWW & Purple & Yellow & Yellow & Absent & Grey \\
\hline & $\mathrm{P}_{2(\text { (क) }}$ & rriiTTWW & Purple & Brown & Brown & Absent & Grey \\
\hline & $\mathrm{P}_{3(\delta)}$ & RRiitittww & White & Yellow & Black & Present & Brown \\
\hline A & $\mathrm{F}_{1}\left(\mathrm{P}_{3} \times \mathrm{P}_{1}\right)$ & RrIi'TtWw & Purple & Yellow & Grey & Absent & Brown \\
\hline $\mathrm{B}$ & $\mathrm{F}_{1}\left(\mathrm{P}_{3} \times \mathrm{P}_{2}\right)$ & RriitiWw & Purple & Yellow & Black & Absent & Brown \\
\hline
\end{tabular}

The cross B from parents contrasting in the bleeding hilum trait shows that the inheritance of this trait in soybean seeds has a monogenic segregation pattern with complete phenotype dominance of absence over presence of bleeding hilum (3:1) (Table 2). Likewise, Carpentieri-Pípolo et al. (2007) reached a similar conclusion. 
The bleeding hilum inheritance was determined only for soybean seeds with yellow seed coat since visualization is much easier for light colored coats. The colored (pigmented) seeds were grouped in a different phenotypic class and the following phenotypic proportions (9:3:4) for yellow seed coats and no bleeding: yellow seed coats and bleeding: pigmented seeds were obtained by the Chi-square test. The estimated $X^{2}$ was $1.341(\mathrm{P}=$ 0.51 ), demonstrating that the observed results fit the hypothetical proportion studied. The $\mathrm{F}_{2: 3}$ population resulting from the 'BRSMG $810 \mathrm{C}$ ' $\mathrm{x}$ 'BRSMG $800 \mathrm{~A}^{\prime}$ crossbreeding had a remarkable difference regarding trait expression for the genotypes carrying the double recessive gene that controls bleeding hilum, however, the existence of a more complex genetic control was discarded due to the non-rejection of the monogenic hypothesis. Ramalho et al. (2012) described expressivity as the way allele is expressed either uniform or variable, i.e., allele expression results in the appearance of several patterns of phenotypes or degrees of expression.

Table 2. Phenotypic segregation of the $F_{2: 3}$ generation for the crosses A ('BRSMG $810 C^{\prime} \mathrm{x}$ 'BRSMG 790 A') and B ('BRSMG 810C' $\mathrm{x}$ 'BRSMG $800 \mathrm{~A}$ ') for studying the inheritance of bleeding hilum (BH) and pubescence color traits in soybean seeds.

\begin{tabular}{|c|c|c|c|c|c|c|c|c|c|c|}
\hline \multirow{3}{*}{ Crosses } & \multirow{3}{*}{ Phenotypes } & \multicolumn{3}{|c|}{ Seed coat color } & \multirow{3}{*}{$X^{2}$} & \multirow{3}{*}{$\mathrm{P}$} & \multicolumn{4}{|c|}{ Pubescence color } \\
\hline & & \multicolumn{2}{|c|}{ Yellow } & \multirow[b]{2}{*}{ Pigmented } & & & \multirow{2}{*}{$\begin{array}{l}\text { Brown } \\
\text { (Genotype } T_{-} \text {) }\end{array}$} & \multirow{2}{*}{$\begin{array}{l}\text { Grey } \\
\text { (Genotypes tt) }\end{array}$} & \multirow[b]{2}{*}{$X^{2}$} & \multirow[b]{2}{*}{$\mathrm{P}$} \\
\hline & & With BH & $\begin{array}{l}\text { Without } \\
\mathrm{BH}\end{array}$ & & & & & & & \\
\hline \multirow{2}{*}{ A } & Observed & 0 & 317 & 0 & 0 & 1.00 & 249 & 68 & 2.129 & 0.14 \\
\hline & Expected & 0 & (317) & 0 & - & - & (237.80) & (79.25) & - & - \\
\hline \multirow{2}{*}{ B } & Observed & 71 & 190 & 96 & 1.34 & 0.51 & 270 & 86 & 0.135 & 0.71 \\
\hline & Expected & $(66.93)$ & 200.80 & $(89.24)$ & - & - & $(267.00)$ & $(89.00)$ & - & - \\
\hline
\end{tabular}

Through phenotypic evaluation, there is evidence of a $\mathrm{T}$ gene that controls the pubescence color trait is linked with the expression of the bleeding hilum trait. Thus, only genotypes with brown pubescence ( $\mathrm{T}_{-}$) presented the bleeding hilum trait. Consequently, plants with a pubescence phenotype characterized as gray (tt) did not have the bleeding hilum phenotype. Carpentieri-Pipolo et al. (2007) also reported this genetic relationship between pubescence and bleeding traits, although they emphasized the existence of pleiotropy.

No segregation was observed in the $\mathrm{F}_{2: 3}$ population derived from 'BRSMG $810 \mathrm{C}$ ' $\mathrm{x}$ 'BRSMG 790A' for the bleeding hilum trait, which may be related to the presence of inhibitory genes. This hypothesis should be confirmed in further studies due to the importance of the bleeding hilum trait for grain acceptability by the consumers.

The pubescence color trait is controlled by a gene with complete dominance (3 brown: 1 gray) for both crosses $\mathrm{A}\left(X^{2}=2.129 ; \mathrm{P}=0.14\right)$ and $\mathrm{B}\left(X^{2}=0.135 ; \mathrm{P}=0.71\right)$ (Table $2)$. In both crosses, the action of four independent genes (R/I/W/T) was the best fit for the observed proportions of seed coat color and hilum color (Table 3). Phenotypic variation was observed for hilum color for the crossbreeding A as evidenced by the number of phenotype classes found for the contrasting parents, 'BRSMG 810C', black hilum and 'BRSMG 790A', yellow hilum.

Considering all the interactions for genetic control of hilum color, the following phenotypic ratio was tested for the cross A (178.30: 59.48: 55.72: 23.50) for gray hilum: yellow hilum: black hilum: brown hilum, respectively. For the phenotypic proportions 
observed in the generation $\mathrm{F}_{2: 3}$, the inheritance controlled by all four genes is the best to explain the inheritance of the hilum color trait $\left(X^{2}=7.184 ; \mathrm{P}=0.20\right)$ (Table 3$)$. In the study of genetic control for seed coat and hilum color in the cross B ('BRSMG 810C' - yellow seed coat and black hilum $x$ 'BRSMG 800A' - brown seed coat and hilum), the genes action R/I/T/W was tested but the phenotype classes did not fit the hypothesis tested $\left(X^{2}=17.64, \mathrm{P}=0.005\right)$ (Table $3)$.

Considering all the interactions for the genetic control of seed coat and hilum color, and inhibition of $\mathrm{W}$ and $\mathrm{T}$ genes in genotypes ii for the cross $\mathrm{B}$, the hypothesis was tested for the following phenotypic ratio (200.25: 66.75: 61.19: 27.81) for yellow seed coat and black hilum: yellow seed coat and brown hilum: black seed coat and hilum: brown seed coat and hilum, respectively. The hypothesis test considering the inhibition of the W/T modifier genes in genotypes ii provided the expected phenotypic frequencies for generation $\mathrm{F}_{2: 3}\left(X^{2}=2.626 ; \mathrm{P}=\right.$ 0.45 ). Thus, the inheritance of the hilum and seed coat color is controlled by four genes in cross $\mathrm{B}$, in which the W/T modifying genes are inhibited in genotypes ii.

Table 3. Phenotypic segregation of generation $F_{2: 3}$ in the cross A ('BRSMG $810 C^{\prime}$ ' $x$ 'BRSMG 790A') for studying the inheritance of hilum color in soybeans; and in cross B ('BRSMG $810 C^{\prime}$ ' $\mathrm{x}$ 'BRSMG 800A') for studying the inheritance of hilum and seed coat color in soybean.

\begin{tabular}{|c|c|c|c|c|c|c|c|c|c|c|c|c|}
\hline \multirow{3}{*}{ Genotypes } & \multicolumn{4}{|c|}{ Hilum color } & \multicolumn{8}{|c|}{ Seed coat color } \\
\hline & \multirow[t]{2}{*}{ Grey $^{(1)}$} & \multirow[t]{2}{*}{ Yellow } & \multirow[t]{2}{*}{ Black } & \multirow[t]{2}{*}{ Brown } & \multirow[t]{2}{*}{$X^{2}$} & \multirow[t]{2}{*}{$\mathbf{P}$} & \multirow{2}{*}{$\begin{array}{l}\text { Yellow } \\
\text { Black }\end{array}$} & \multicolumn{2}{|c|}{$\begin{array}{l}\text { Black } \\
\text { Hilum color }\end{array}$} & \multirow{2}{*}{$\begin{array}{l}\text { Brown } \\
\text { Brown }\end{array}$} & \multirow[t]{2}{*}{$X^{2}$} & \multirow[t]{2}{*}{$\mathbf{P}$} \\
\hline & & & & & & & & Brown & Black & & & \\
\hline 'BRSMG 810C' & 0 & 0 & 55 & 0 & 0 & 1.00 & 55 & 0 & 0 & 0 & 0 & 1.00 \\
\hline 'BRSMG 790A' & 0 & 65 & 0 & 0 & 0 & 1.00 & - & - & - & - & - & - \\
\hline 'BRSMG 800A' & - & - & - & - & - & - & 0 & 0 & 0 & 70 & 0 & 1.00 \\
\hline $\mathrm{F}_{2: 3}$ - Observed & 178 & 56 & 50 & 33 & - & - & 196 & 65 & 59 & 36 & & - \\
\hline$\left(\mathrm{F}_{2: 3} \text {-Expected }\right)^{(2)}$ & $(178.30)$ & $(59.48)$ & $(55.72)$ & $(23.50)$ & 7.18 & 0.20 & $(200.25)$ & $(66.75)$ & (61.19) & $(27.81)$ & 2.626 & 0.45 \\
\hline$\left(\mathrm{F}_{2: 3}-\text { Expected }\right)^{(3)}$ & - & - & - & - & - & - & $(167)$ & $(78)$ & $(84)$ & $(28)$ & 17.64 & 0.005 \\
\hline
\end{tabular}

${ }^{(1)}$ Genotypes I_R_ T ${ }_{-}$and I_R_ttW

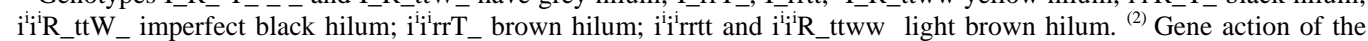
$\mathrm{R} / \mathrm{I} / \mathrm{T} / \mathrm{W}$ loci considering gene $\mathrm{i}$ acting as blocker of the $\mathrm{T}$ and $\mathrm{W}$ genes acting on the expression of hilum and seed coat color for cross B. ${ }^{(3)}$ Gene action of the R/I/T/W loci considering the gene $\mathrm{i}$ not blocking the $\mathrm{T}$ and $\mathrm{W}$ genes acting on the expression of hilum and seed coat color.

\section{CONCLUSIONS}

The bleeding hilum presents monogenic genetic control with complete dominance of absence over presence of the trait. Double recessive genotypes with bleeding hilum have variable expressiveness. There are some genes inhibiting the phenotype presence of bleeding hilum in the 'BRSMG $810 \mathrm{C}^{\prime} \mathrm{x}$ 'BRSMG 790A' cross. Brown pubescence in soybean seeds is determined by the $\mathrm{T}_{-}$genotype, which is linked to the presence of bleeding hilum;

For both crosses, the gene action of four genes (R/I/T/W) allows adjusting the proportions observed for the qualitative trait, color of the hilum and seed coat, but the presence of genotype ii inhibits the action of modifier locus $\mathrm{T}$ and $\mathrm{W}$ in the expression of hilum and seed coat pigmentation in soybean seeds.

These crosses are promising. The artificial hybridization promoted sufficient genetic variability for the selected soybean seeds with different seed coat and hilum colors. This should allow us to obtain soybean cultivars that are more acceptable for human consumption. 


\title{
ACKNOWLEDGMENTS
}

\author{
Research supported by FAPESP (Fundação de Amparo à Pesquisa do Estado de São \\ Paulo), Process: FAPESP 2012/15371-1.
}

\section{CONFLICTS OF INTEREST}

\author{
The authors declare no conflict of interest.
}

\section{REFERENCES}

Arantes NE, Zito RK, Zanetti AL, Fronza V, et al. (2010). Cultivares de soja: Minas Gerais e Região Central do Brasil Safra 2010/2011. Available at [https://www.embrapa.br/soja/busca-de-publicacoes/-/publicacao/898048]. Accessed 7 Oct 2015

Bhatt GM and Torrie JH (1968). Inheritance of pigment color in the soybean. Crop Sci. 8 (5): 617-619.

Borém A and Miranda GV (2005). Melhoramento de plantas. 4st edn. UFV, Viçosa.

Brasil. Lei no 9.456, de 25 de abril de 1997. Institui a Lei de Proteção de Cultivares e dá outras providências. Available at [http://www.planalto.gov.br/ccivil_03/LEIS/L9456.htm]. Acessed 15 aug 2015.

Carpentieri-Pípolo V, Souza A, Almeida LA, Kiihl RAS, et al. (2007). Herança de hilo esparramado em sementes de soja. Pesqui. Agropec. Bras. 42 (1): 127-129.

Carpentieri-Pipolo V, Almeida LA de, Kiihl RAS, et al. (2015). Inheritance of R Locus expressing Brown hilum on Black seed coat in soybean. Am. J. Plant Sci. 6(11): 1857-1861.

Cruz CD (2013). GENES: A software package for analysis in experimental statistics and quantitative genetics. Acta Sci. 35 (3): $271-276$

Fehr WR and Canivess CE (1977). Special Report 80, Iowa Agricultural Experiment Station, Iowa Cooperative External Series, Iowa State University, Ames.

Juhász ACP, Ciabotti S, Pádua GP, Favoreto L, et al. (2014). Melhoramento de soja para alimentação humana. In: Informe Agropecuário: Inovações, tecnologias e sociedade: 40 anos EPAMIG. 39-45. Available at [https://ainfo.cnptia.embrapa.br/digital/bitstream/item/114632/1]. Accessed 10 Oct 2019.

Gillman JD, Tetlow A, Lee JD, Shannon JG, et al. (2011). Loss-of Function Mutations Affecting a Specific Glycine max R2R3 MYB Transcription Factor Result in Brown Hilum and Brown Seed Coats. BMC Plant Biol. 11: 155-167.

Mahmud I and Probst AH (1953). Inheritance of gray hilum color in soybeans. Agron. J. 45: 59-61.

Morse WJ and Carter JL (1937) Improvement in soybeans. Yearbook of agriculture. 1154-1189.

Nagai JA (1921). Genetic physiological study on the formation of anthocyanin and brown pigments in plants. Tokyo Un. Coll. of Agri. J. 8: 1-92.

Nogueira APO, Sediyama T, Oliveira RCT, Glasenapp JS, et al. (2015) Caracteres Qualitativos. In: Melhoramento Genético de Soja (Sediyama T, ed.). Mecenas, Londrina.

Owen FV (1927). Inheritance studies in soybeans. II Glabousness color of pubescence, time of maturity, and linkage relations. Genetics. 12(6): 519-529.

Payne R and Morris L (1976). Differentiation of soybean cultivars by seedling pigmentation patterns. J. Seed Technol. 1(1): $1-9$.

Rabel M, Vieira ESN, Lana UGP, Paiva E, et al. (2010). Marcadores Moleculares microssatélites na avaliação de sementes de soja com variação na coloração do hilo. Rev. bras. Sementes. 32 (2): 19-25.

Ramalho MAP, Santos JB, Pinto CABP, Souza EA, et al. (2012). Genética na agropecuária. UFLA, Lavras.

Senda M, Kurauchi T, Kasai A, Ohnishi S (2012). Suppressive Mechanism of Seed Coat Pigmentation in Yellow Soybean. Breed Sci. 61 (5): 523-530.

Silva JB, Carrão-Panizzi MC and Prudêncio SH (2009). Chemical and physical composition of grain-type and food-type soybean for food processing. Pesq. Agropec. Bras. 44: 777-784.

Terao H (1918). Maternal inheritance in the soybean. Amer. Nat. 52 (613): 51-56.

Vernetti FJ and Vernetti Júnior FJV (2009). Genética da soja: caracteres qualitativos e diversidade genética. Embrapa, Pelotas.

Weiss MG (1970). Genetic linkage in soybeans. Linkage groups II and III. Crop Sci. 10 (3): 300-303.

Williams LF (1952). The inheritance of certain black and brow pigments in the soybean. Genetics. 37 (2): 208-215.

Yang K, Jeong N, Moon JK, Lee YH, et al. (2010). Genetic Analysis of Genes Controlling Natural Variation of Seed Coat and Flower Colors in Soybean. J. Hered. 101(6): 757-768. 